\title{
DEFLUORIDATION EFFECT OF TULSI (OCIMUM SANCTUM, LAMINAACE) ON GROUND WATER
}

\author{
B. V. Sudheer ${ }^{1}$, Shaik Ahmed ${ }^{2}$
}

${ }_{1}^{1}$ Faculty Members, Department of General Medicine, Guntur Medical College, Guntur, Andhra Pradesh. ${ }^{2}$ Faculty Members, Department of General Medicine, Guntur Medical College, Guntur, Andhra Pradesh.

\begin{abstract}
Tulasi is known for its therapeutic value, as it contains number of photochemicalwhich possesses antibacterial, antiviral, antioxidant and adaptogenic properties. Studies carried out by some workers showed that the Tulasi is effective in removal of $95 \%$ fluoride from ground water with in $20 \mathrm{mts}$. The effect of Tulasi on fluorinated water studied by some authors revealed that it has negligible defluoridation property. In the present study, the defluorination effect of Tulasi on ground water was studied and it found to be variable. Among the 31 samples studied showed that the fluoride content raised in 27 samples, decreased in 4 samples and no change in 12 samples after treating with Tulasi.
\end{abstract}

\section{KEYWORDS}

Tulasi (Ocimum Sanctum), Ground Water, Defluoridation.

HOW TO CITE THIS ARTICLE: Sudheer BV, Ahmed S. Defluoridation effect of tulsi (ocimum sanctum, laminaace) on ground water. J. Evolution Med. Dent. Sci. 2016;5(56):3877-3879, DOI: 10.14260/jemds/2016/887

\section{INTRODUCTION}

Water is an important requirement for human life to exist. Though ground water contains some impurities, the presence of fluoride with concentration $>1.5 \mathrm{ppm}$ will cause hazards to human health. It can cause dental fluorosis, skeletal fluorosis, etc.

In India, people of 196 districts are drinking fluoride contaminated water above maximum allowed concentration (MAC) of 1.5 ppm (Goswami et al, 2004). ${ }^{1}$ Concentration of fluoride in drinking water in different parts of India varies between 0.5 to $50 \mathrm{ppm}$. Out of 6 lakh villages in India, at least $50 \%$ have fluoride content in drinking water exceeding 1.0 ppm (Gupta, 1995).

Fluoride ingested through water is considered as the principle cause of fluorosis in endemic areas (Somvanshi et al 1990) despite the fact that in many areas fluorosis ingested through food is also known to be critically high.

The amount of water that is ingested varies widely with age, climatic conditions, bodyweight, muscular activity, dietary habits and socio-economic conditions. So the average fluoride ingested through drinking water varies widely with climatic conditions in non-endemic areas also. The presence of fluoride in water provides a substantial reduction in dental caries of human, but if the concentration exceeds $1.5 \mathrm{ppm}$ it causes several adverse effects like mottling of teeth called dental fluorosis, skeletal fluorosis, crippling fluorosis, osteoporosis, etc.

Varies methods have been evolved to remove excess of fluoride concentration from water. These methods are based on the principle of adsorption, ion exchange, precipitation, electrodialysis and reverse osmosis. Nawlakhe et al (1974) stated addition of aluminium as defluoriding agent with increasing concentration of fluoride and alkalinity of raw water.

Financial or Other, Competing Interest: None.

Submission 20-06-2016, Peer Review 05-07-2016,

Acceptance 07-07-2016, Published 14-07-2016.

Corresponding Author:

Dr. B. V. Sudheer,

Faculty Members,

Department of General Medicine,

Guntur Medical College,

Guntur, Andhra Pradesh.

E-mail: bvsudheer56@yahoo.com

DOI: $10.14260 /$ jemds $/ 2016 / 887$
The adsorption behaviour of fluoride on synthetic hydrous zirconium oxide was investigated by Goswami et al (2004). ${ }^{1}$

To implement these techniques for defluoridation of water much difficulties has to overcome such as cost, effectiveness, acceptability, adaptability, etc. An attempt was made to find out effective and efficient method for reduction of excess fluoride concentration within the permissible limit of Indian Standard for drinking water. Studies were carried out by using basil leaves, stems and leaf extract to remove the excess fluoride concentration.

\section{MATERIALS AND METHOD}

Ground water samples of different locations are collected with necessary precautions (Brown et al 1974). The fluoride concentration was measured by using "Zirconium-alizarin visual method." To execute the study, $100 \mathrm{mg}$ of Tulasi powder (Tulasi Powder Contains - leaves, stem, flower, root, seeds and even whole plant) is added to $100 \mathrm{~mL}$ of fluorinated water having more than 2 ppm fluoride and kept for $12 \mathrm{hrs}$. after thorough mixing. As the samples developed colour change, they were decolorized by the addition of activated charcoal and filtered with Gr. 1 filter paper (Whatman qualitative filter paper having 11 um used for clarifying liquids) and then fluoride content was measured with same method.

\section{RESULTS AND DISCUSSION}

The raw water fluoride concentration and fluoride concentration after treatment with Tulasi for 12 hours was shown in Table 1. It is noted that there is variable results of fluoride concentration after treatment with Tulasi shown in Table 2 and Figure 1.

\begin{tabular}{|c|c|c|c|c|c|}
\hline $\begin{array}{c}\text { Sl. } \\
\text { No. }\end{array}$ & $\begin{array}{c}\text { Initial F } \\
\text { con } \\
\text { ppm }\end{array}$ & $\begin{array}{c}\text { Tulasi } \\
\mathbf{R x} \\
\mathbf{p p m}\end{array}$ & $\begin{array}{c}\text { Sl. } \\
\text { No. }\end{array}$ & $\begin{array}{c}\text { Initial F } \\
\mathbf{c o n} \\
\mathbf{p p m}\end{array}$ & $\begin{array}{c}\text { Tulasi } \\
\mathbf{R x} \\
\mathbf{p p m}\end{array}$ \\
\hline 1 & 2.2 & 2.2 & 17 & 4.4 & 5.2 \\
\hline 2 & 2.6 & 2.6 & 18 & 2.2 & 3.0 \\
\hline 3 & 4.4 & 4.4 & 19 & 2.2 & 3.0 \\
\hline 4 & 3.4 & 3.4 & 20 & 2.6 & 3.3 \\
\hline 5 & 3.6 & 3.6 & 21 & 2.6 & 3.0 \\
\hline 6 & 2.2 & 2.2 & 22 & 2.0 & 2.2 \\
\hline 7 & 2.0 & 2.0 & 23 & 2.2 & 2.6 \\
\hline 8 & 2.6 & 2.6 & 24 & 9.0 & 7.0 \\
\hline
\end{tabular}




\begin{tabular}{|c|c|c|c|c|c|}
\hline 9 & 2.6 & 2.6 & 25 & 2.2 & 1.8 \\
\hline 10 & 2.2 & 2.2 & 26 & 2.6 & 2.2 \\
\hline 11 & 2.2 & 2.2 & 27 & 2.2 & 2.0 \\
\hline 12 & 3.0 & 3.0 & 28 & 2.8 & 3.0 \\
\hline 13 & 3.6 & 4.4 & 29 & 3.6 & 3.0 \\
\hline 14 & 2.2 & 3 & 30 & 2.2 & 2.4 \\
\hline 15 & 2.8 & 3.6 & 31 & 5.2 & 6.0 \\
\hline 16 & 2.8 & 3.0 & & & \\
\hline \multicolumn{7}{|c|}{ Table 1: Fluoride Concentration Before \& } \\
\hline
\end{tabular}

\begin{tabular}{|c|c|c|c|c|}
\hline $\begin{array}{c}\text { No. of } \\
\text { Samples }\end{array}$ & $\begin{array}{c}\text { Initial } \\
\text { ppm }\end{array}$ & \multicolumn{3}{|c|}{ After ppm } \\
\hline & & Raised & Fall & $\begin{array}{c}\text { No } \\
\text { Change }\end{array}$ \\
\hline 22 & 2 to 2.9 & $11(50 \%)$ & $\begin{array}{c}3 \\
(13.63 \%)\end{array}$ & $\begin{array}{c}8 \\
(36.36 \%)\end{array}$ \\
\hline 5 & 3 to 3.9 & $1(20 \%)$ & $1(20 \%)$ & $3(60 \%)$ \\
\hline 4 & $\begin{array}{c}4 \text { and } \\
\text { above }\end{array}$ & $3(75 \%)$ & 0 & $1(25 \%)$ \\
\hline 31 & & $\begin{array}{c}15 \\
(48.38 \%)\end{array}$ & $\begin{array}{c}4 \\
(12.9 \%)\end{array}$ & $\begin{array}{c}12 \\
(38.7 \%)\end{array}$ \\
\hline
\end{tabular}

Table 2: Variations in Fluoride ppm after Treatment of Tulasi

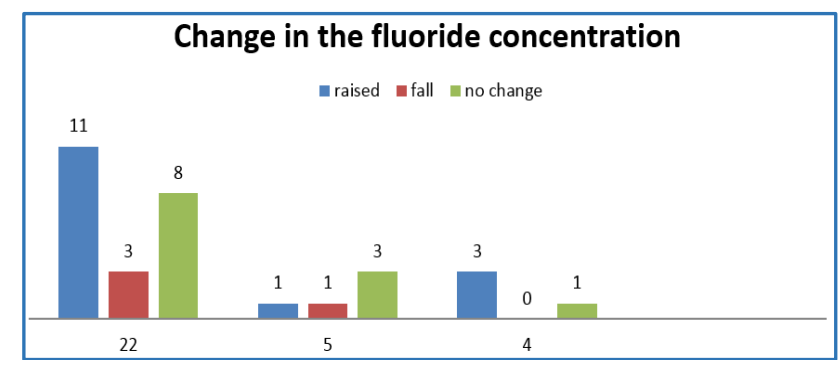

Fig. 1: The Water Having 2 to 2.9 ppm Initially had Raised ppm in 50\% (11) of Cases, Fall in 13.6\% (3) and No Change in $36.36 \%$ (8) After Adding Tulasi Powder

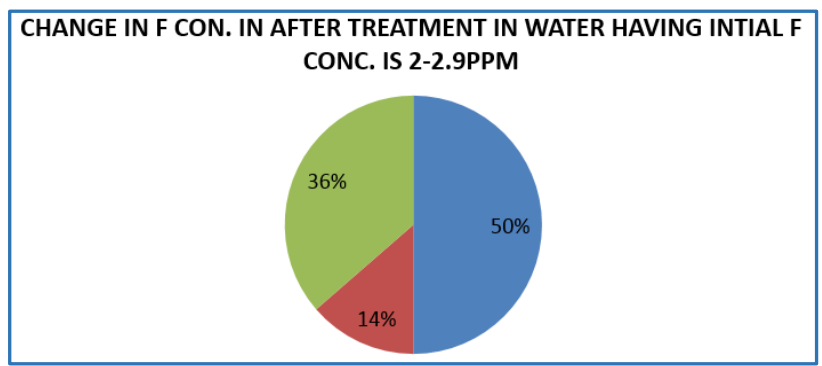

Fig. 2: The Water Having 2 to 2.9 ppm Initially had Raised ppm in 50\% (11) of Cases, Fall in 13.6\% (3) and No Change in 36.36\%(8) After Adding Tulasi Powder

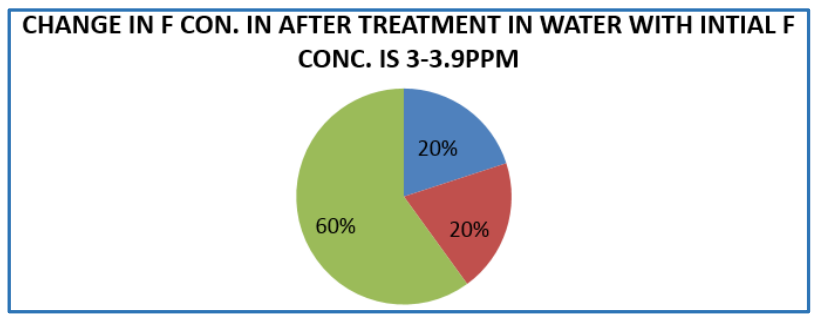

Fig. 3: In Samples Having 3 to 3.9 ppm Samples (5) Showed No Change in $60 \%$ (3), Rise in $20 \%$ (1), and Fall in $20 \%$ of Cases

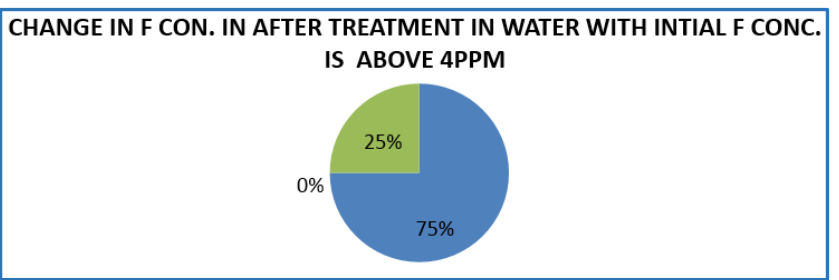

Fig. 4: The Water Having 4 ppm and Above (4) Showed that $75 \%$ (3) Rise and 25\% (1) No Change in Fluoride Concentration

The defluoridating effect of Tulasi was studied by various authors. The effect of Tulasi leaves on fluoridated water studied observed that it has negligible defluoridation property. ${ }^{2}$ It was reported earlier that fresh, dried leaves and stem of Tulasi plant had a fluoride reported efficiency of 74 to 78\%.3,4,5 (Raaz Maheshwari and Bina Rani, 2013; Kamble, 2012; Raaz et al 2012).

From the results of earlier studies concluded that Tulasi leaves and stem (Fresh and dry) can be used as defluoridating agent. It can remove $80 \%$ of fluoride from the synthetic solution. The resulting concentration of fluoride after treatments with tulasi comes within the permissible limit of Indian Standard for drinking water (IS 10500:1991, Fluoride 1.0-1.5 ppm). ${ }^{6}$

In this study Tulasi has $48.38 \%$ adverse defluoridation effect, $38.7 \%$ no effect and $12.9 \%$ has beneficial defluoridation effect.

\section{CONCLUSION}

In the present study, it is observed that on treating the ground water samples containing high fluoride concentration with Tulasi powder (Mixture of leaves, stem and flowers and roots), there is a variable change in fluoride concentration. In the study, it is observed that there is rise of ppm in $48.38 \%$ (15), fall in $12.9 \%$ (4) and no change in $38.7 \%$ (12) in Conc of Fluoride with treatment of Tulasi. From this study, it is concluded that there is no fixed change in the concentration of fluoride in ground water samples on treating it with Tulasi and further it is showing more adverse effect by rising fluoride concentration in $48.38 \%$ of samples than beneficial effect by fall in fluoride concentration in $12.9 \%$ of samples.

\section{ACKNOWLEDGEMENT}

Authors thank the Water Analysts of Regional Public Health Laboratory, Guntur, A.P., for providing necessary laboratory facilities and assistance for analysis of water.

\section{REFERENCES}

1. Goswami. Studies on removal of fluoride by hydrated zirconium oxide (HZO) chem. Env Res 2004;13(1-2):11726.

2. Sudarshan V, Narsimha A, Geeta S, et al. Efficacy of tulasi for removal of fluoride in ground water. International journal of Recent Scientific Research Research 2014;5(7):1236-8.

3. Maheswari R. Multifaceted usage of holy basil. Journal of Drug Discovery and Therapeutics 2013;1(5):01-04.

4. Kamble R. Tulsi fights fluorosis. Downto Earth 2012;10(1):53. 
5. Raazmaheswari, Bina R, Rajeshkumaryadav, et al. Usage of holy basil for various aspects. Bulletin of Environment Pharmocology and Life Sciences 2012;1(10):67-9.
6. APHA. Standard methods for the examination of water and wastewater. 17th ed. American public Health Association, Washington, DC 1991. 